\title{
MAKNA CANTIK DALAM IKLAN \\ MAGNIFICENT MEANING IN ADVERTISING
}

\author{
Freddy Yusanto, S.Sos., M.Ds ${ }^{1)}$, Adinda Giani Putri ${ }^{2)}$ \\ Prodi Ilmu Komunikasi, Fakultas Komunikasi dan Bisnis, Universitas Telkom ${ }^{1)}$ \\ fredyusanto@gmail.com ${ }^{1,}$ adindagiani@gmail.com ${ }^{2}$
}

\begin{abstract}
Abstrak
Banyak paham yang menjelaskan mengenai definisi cantik yang dinilai dari kecantikan luar diri (outer beauty) dan kecantikan dari dalam diri (inner beauty), tetapi masih banyak perempuan di Indonesia yang hanya mempersepsikan cantik itu berkulit putih, berambut hitam panjang dan bertubuh langsing. Produk Clean \& Clear mencoba melihat makna cantik dari sudut pandang yang berbeda. Cantik itu tidak harus putih, berambut panjang dan berbadan langsing, oleh karena itu iklan Clean \& Clear mencoba untuk menampilkan model perempuan yang notabene tidak seperti persepsi 'cantik' seorang perempuan pada umumnya.

Penelitian ini bertujuan untuk mengetahui makna outer beauty dan inner beauty dalam iklan Clean \& Clear versi '1000 suku Indonesia, warna kulit berbeda'. Metode yang digunakan dalam penelitian adalah metode penelitian kualitatif dengan menggunakan analisis semiotika Roland Barthes yang melihat tanda dari denotasi, konotasi, dan mitos berdasarkan paradigma kritis. Teknik pengumpulan data yang digunakan yaitu iklan Clean \& Clear versi '1000 suku Indonesia, warna kulit berbeda sebagai data primer serta referensi buku, karya tulis dan artikel sebagai data sekunder.

Hasil penelitian menunjukkan bahwa secara denotasi dan konotasi, iklan Clean \& Clear mencoba menonjolkan inner beauty melalui kepercayaan diri yang tinggi, senyum lepas yang menunjukkan kebahagiaan para perempuan yang notabene secara outer beauty, mereka tidak memiliki kulit putih dan rambut hitam panjang. Namun dalam iklan ini, peneliti melihat ada satu komponen kecantikan yang tetap dipertahankan oleh Clean \& Clear, yaitu badan yang langsing. Dari ke Sembilan model perempuan yang ditampilkan dalam iklan ini, semuanya berbadan langsing. Padahal kita tahu, tidak sedikit perempuan yang tidak langsing dan juga ingin terlihat cantik.
\end{abstract}

Kata Kunci : Semiotika, Iklan Clean \& Clear, Inner beauty, Outer beauty. 


\begin{abstract}
Many theories explain the definition of beauty; it is said that it is seen from their outer beauty and inner beauty, however many Indonesian women still have a strong perception that beautiful women are the ones with bright skin, long hair and slim.Clean \& Clear products try to see the meaning of beautiful from its different point of view. It should not be white, long-haired and slim, therefore Clean \& Clear ads show female models with different perception of 'beautiful' women in general.

This study aims to determine the meaning of outer beauty and inner beauty in Clean \& Clear ads version of '1000 tribes Indonesia, different skin colors'. The method used in this research is qualitative research by using semiotics analysis Roland Barthes by focusing on the sign of denotation, connotation, and myth based on critical paradigm. Data collection techniques used here are Clean \& Clear ads version of '1000 Indonesian tribe, different skin color as the primary data and reference book, paper and article as the secondary data.

The result of study shows that Clean \& Clear ads try to highlight inner beauty through high confidence, a loose smile showing the happiness of women who are seen different from their outer beauty, they do not have bright skin and long black hair. Otherwise in this ad, researchers see there is one component of beauty still maintained by Clean \& Clear, that is about a slim body. It is seen from the nine female models featured in this ad, all of them are slim. As we all know that many women who are not slim, they are still obsessed to look beautiful.

Keywords: Semiotics, Advertising \& Clear, Inner beauty, Outer beauty.
\end{abstract}

\title{
PENDAHULUAN
}

Iklan televisi merupakan media yang menyampaikan pesan tentang suatu produk melalui Televisi (Wijayanti, 2009: 31). Industri di Indonesia biasanya menggunakan iklan komersial untuk memasarkan produk atau jasa mereka, salah satunya adalah iklan produk kecantikan perempuan. Mitos kecantikan yang terbangun di dalam masyarakat, seringkali membuat perempuan kemudian memaksakan diri agar 'terlihat' cantik. Pada dasarnya, kecantikan terbagi dua, yaitu kecantikan fisik dan non fisik atau istilah populernya adalah inner beauty dan outer beauty. Inner beauty merupakan kecantikan bagian dalam atau kecantikan batiniah yang tidak berwujud yang membuat perempuan selalu tampak mengesankan, sedangkan outer beauty adalah kecantikan yang dinilai dari keindahan fisik bukan dinilai dari kepribadiannya (Wijayanti, 2009:5). Ketika perempuan ingin tampil cantik, maka produk pemutih bermunculan untuk 'membantu' perempuan agar menjadi 'cantik'. Ketika perempuan ingin cantik, maka produk perawatan rambut kemudian datang dengan segudang solusi permasalahan rambut. Ketika perempuan ingin terlihat cantik, maka produk pelangsing berlomba menjadi pahlawan para perempuan pemuja tubuh langsing.

Di negara Korea Selatan cantik di konstruksikan dengan perempuan yang memiliki mata mata dan katung mata yang besar, sedangkan perempuan Korea Selatan pada dasarnya memiliki mata yang kecil dan tidak memiliki kantung mata dan di negara Eropa konstruksi perempuan cantik merupakan perempuan yang memiliki jenis kulit yang gelap, sedangkan perempuan Eropa memiliki jenis kulit yang terang. Bagi perempuan di negara Ghana cantik itu memiliki jenis pinggul yang besar, sedangkan perempuan yang ada di negara tersebut tidak memiliki pinggul yang besar. Artinya, bahwa cantik itu bersifat kultural, sangat bergantung 
pada kultur yang ia tempati. Hal ini membuktikan bahwa cantik tidak dapat digambarkan oleh ciri fisik, karena kontruksi cantik di berbagai negara memiliki arti yang berbeda-beda.

Konsep cantik, pada dasarnya sudah ada sejak dahulu. Menurut beberapa mitologi, patung, dan lukisan kuno yang menggambarkan tubuh perempuan merupakan representasi sebuah kecantikan. Dahulu masyarakat menilai perempuan yang memiliki bentuk tubuh gemuk adalah perempuan yang cantik. Gemuk di artikan sebagai perempuan yang memiliki kesejahteraan hidup, sedangkan perempuan dengan tubuh kurus menurut suku Masai di anggap sebuah kutukan sehingga perempuan dengan tubuh kurus harus dibakar agar kutukan tersebut tidak menyebar pada perempuan lain. Lukisan klasik pada abad pertengahan di Barat, tubuh perempuan dilukiskan dengan tubuh yang subur, dengan perut yang besar, lengan yang berisi, dan wajah yang berdaging. Tubuh perempuan yang ideal adalah gemuk dan berlekuklekuk. Patung bernama Venus Of Willendrof memperlihatkan bahwa dewi Venus sebagai simbol kecantikan pun bertubuh gemuk. Berbeda dengan masyrakat Romawi, mereka kurang menyukai perempuan berbadan langsing, tetapi lebih menyukai perempuan dengan bentuk tubuh berisi atau gempal, sedangkan masyarakat di Andalusia (Spanyol) menyukai perempuan ysng memiliki ukuran ikat pingga selebar pingga laki-laki (Wijayanti, 2009: 9). Perubahan konsep cantik muncul di tahun 1960-1970. Seorang model bernama Twiggy, perempuan dengan tinggi badan $170 \mathrm{~cm}$, berat badan $47,5 \mathrm{~kg}$ serta memiliki rambut lurus, menjadi idola baru. Para perempuan pada masa itu mati-matian untuk tampil seperti Twiggy. Standar kecantikan ala Twiggy ini menjadi sebuah konsep cantik bagi perempuan, hingga saat ini (Wijayanti, 2009:11).

Salah satu produk kecantikan yang kemudian memiliki andil besar dalam memperkuat struktur cantik ala Twiggy adalah iklan sabun mandi LUX. Iklan LUX menggunakan artis Hollywod berkulit putih dan langsing sebagai model iklannya. Seperti Joan Caulfied pada tahun 1949, Jaenne Crain pada tahun 1951, Ruth Roman pada tahun 1956, dan Belinda Lee di tahun 1957. Hal tersebut berdampak pada iklan sabun LUX di Indonesia pada tahun 1959 yang menampilakan bintang film Indonesia, dimana cantik tetap dikonstruksi sebagai perempuan yang berkulit putih.

Ketika beberapa perempuan ingin tampil cantik dengan kulit putih yang didukung dengan banyaknya produk-produk pemutih yang bermunculan di pasar. Hal ini ternyata tidak membuat semua produsen berusaha membuat produk sejenis. Contohnya produk Clean \& Clear yang melihat makna cantik dari sudut pandang yang berbeda. Cantik itu tidak harus putih, oleh karena itu Clean \& Clear hadir dengan produk-produknya yang berusaha meningkatkan kepercayaan diri perempuan, sehingga cantik tidak harus dilihat hanya secara fisik. Clean \& Clear merupakan produk kecantikan remaja dari PT. Johnson \& Johnson yang mencoba melihat perbedaan warna kulit tidak mempengaruhi pandangan kita tentang Kehidupan. Penampilan terbaik dan memiliki rasa percaya diri untuk menjadi diri kita sendiri menjadi fokus utama dalam pesan-pesan iklan produk Clean \& Clear. (https://www.cleanandclear.co.id/tentang diakses pada 22 Maret 2017 pukul 05.43 WIB).

Menurut Wijayanti kecantikan merupakan kesempurnaan secara fisik perempuan yang dapat dilihat orang lain, dirasakan oleh perempuan dan ditonjolkan dari kelebihan secara fisik (outer beuty) maupun melalui inner beauty yang dimiliki oleh perempuan. Outer beauty dapat terlihat dari bentuk tubuh langsing, kulit putih, dan berambut hitam panjang. Sedangkan Inner beauty dapat dilihat dari kepribadian yang baik, berintelektual, memiliki kepercayaan diri, dan kharismatik. Hal ini sejalan dengan makna cantik yang dimunculkan pada iklan Clean \& Clear yang menggambarkan bahwa cantik itu bukan hanya dari fisik saja tetapi dari juga kepribadian. Terdapat beberapa scene yang menunjukkan tarian yang enerjik, wajah yang ceria dan tingkat kepercayaan diri yang tinggi. Iklan Clean \& Clear mencoba mendekosntruksi makna cantik sehingga cantik tidak hanya di lihat dari jenis kulit putih dan rambut hitam panjang saja. 
Penulis tertarik untuk membedah makna iklan sabun pembersih wajah Clean \& Clear dengan teknik analisis semiotika Roland Barthes, dengan tujuan untuk mengungkap makna dan pesan yang ada di balik tanda dalam iklan tersebut. Clean \& Clear merupakan produk kecantikan remaja dari PT. Johnson \& Johnson yang memiliki perhatian lebih terhadap kebutuhan kulit para remaja. Secara umum, semiotika Barthes ingin menawarkan suatu metode untuk memperdalam pemahaman terhadap bahasa, sastra, dan masyarakat (Barthes, 2012: 12). Barthes menggagas adanya dua tingkatan signifikan, tingkat pertama denotasi yakni relasi antara penada dan petanda dalam sebuah tanda, serta tanda dengan acuannya dalam realitas eksternal, ini menunjuk pada common-sense atau makna tanda yang nyata. Tingkatan kedua adalah bentuk, konotasi, mitos, dan simbol (Barthes, 2012: 13).

\section{PEREMPUAN DAN KECANTIKAN}

Hingga saat ini, iklan kecantikan masih banyak menggunakan perempuan yang memiliki kulit putih, Hal ini berdampak pada cara pandang para perempuan bahwa memiliki jenis kulit putih, itulah cantik. Melalui kemajuan teknologi yang semakin modern, kecantikan secara fisik lebih mudah terwujud. Perempuan pemuja kecantikan secara fisik kemudian berbondong-bondong memoles bahkan mengubah diri menjadi lebih cantik. Hal ini kemudian dibidik oleh produsen kecantikan dengan banyaknya produk-produk kecantikan perempuan yang dijual di pasaran. Ini bukti bahwa perempuan adalah pasar yang potensial untuk digarap oleh produsen. Karena perempuan adalah segmen pasar yang sangat potensial, maka banyak iklan-iklan yang menampilkan perempuan dengan 3 konsep cantik yaitu kulit putih, rambut hitam panjang serta langsing, untuk 'merayu' para perempuan agar mau menggunakan produk yang diiklankan. Seiring dengan teknologi yang terus berkembang, warna kulit pun dapat dirubah sesuka hati dengan mudah.

Namun, seringkali kita melupakan kecantikan dari dalam (inner beauty). Untuk yang satu ini, belum ada teknologi yang dapat mengubah kecantikan jiwa secepat perubahan fisik. Untuk merubah kecantikan dari dalam, diperlukan proses panjang yang dilakukan terus menerus dan menjadi kebiasaan. Salah satunya adalah percaya diri, dimana percaya diri adalah tindakan yang berani menganalisis dan mensintesa isi sebuah komunikasi, dan yang terpenting adalah rasa berani dalam mengambil keputusan untuk dirinya sendiri (Wijayanti, 2009:84). Mempunyai jiwa percaya diri akan membuat seseorang terlihat memiliki pendirian dalam hidupnya, lebih menghargai dirinya sendiri, dan akan lebih mencintai dirinya sendiri.

Hal yang berkaitan dengan inner beauty yang lain adalah kharisma. Pancaran kharisma merupakan bentuk kepribadian yang baik sehingga bisa menjadi panutan orang-orang di sekitarnya, sikap yang ia miliki dapat mempengaruhi lingkungan sekitarnya, dan mempunyai jiwa seorang pempimpin. Indikasi dari seseorang yang memiliki kharisma adalah visoner. Seseorang yang memiliki kharisma akan memberikan sebuah pencerahan, dan memiliki kepercayaan diri untuk memecahkan sebuah masalah yang ada di lingkunganya. Untuk orang yang memiliki sebuah kharisma ia tidak perlu mengikuti lingkunganya, karena lingkunganlah yang akan mengikutinya tanpa diperintah olehnya (Wijayanti, 2009:84).

Kepribadian yang baik juga dapat dijadikan sebagai bagian dari parameter kecantikan dari dalam (inner beauty) yang baik dapat dilihat bagaimana lingkungan di sekitarnya memiliki rasa nyaman kepada dirinya, kepribadian yang baik akan membuat orang-orang yang disektiranya memiliki perilaku yang baik juga karena sebuah kebaikkan biasanya akan di tanggapi dengan perilaku yang baik juga. Salah satu kepribadian yang baik dapat dilihat dari ekspresi, yaitu senyuman. Senyuman adalah bentuk luapan sebuah emosi yang positif, dan merupakan ekspresi wajah yang paling penting, sebuah senyuman juga melihatkan suasana hati yang positif. Ekspresi wajah tersenyum merupakan salah satu isyarat nonverbal yang paling mudah dikenal, orang yang sedang tersenyum akan terlihat memiliki perasaan 
kebahagiaan, ketertarikan, sebuah semangat hidup, dan menunjukkan rasa empati dan perhatian (Wijayanti 2009:100). Menurut Wijayanti dalam buku Rahasia Cantik Luar Dalam, orang yang banyak tersenyum memiliki daya tarik tersendiri, karena orang yang memiliki ekspresi senyuman akan membuat penampilanya lebih menarik. Ekpresi tersenyum akan membuat perasaan orang lain yang melihatnya menjadi senang dan nyaman. Senyuman dapat mengubah sebuah perasaan. Ketika seseorang sedang sedih dan kemudian mencoba untuk tersenyum maka perasaan sedihnya akan perlahan akan hilang berganti dengan perasaan yang lebih baik. Senyuman membuat suasana lingkungan menjadi lebih riang, karena ketika seseorang tersenyum maka lingkungan yang ada di sekitarnya akan ikut tersenyum.

\section{PEREMPUAN DALAM IKLAN TELEVISI}

Ketika perempuan ditampilkan untuk menciptakan citra tertentu, maka keberadaan perempuan dalam iklan seakan menjadi sebuah keharusan. Bila kita perhatikan, tubuh perempuan seolah dapat mewakili kemewahan sebuah mobil, keindahan sebuah berlian, kesegaran minuman, kegagahan sebuah gedung dan sebagainya. Seakan sangat sulit bagi para pengiklan untuk menghindari keberadaan perempuan dalam iklan. Sebagian orang melihat ini adalah sebuah ekploitasi, namun tidak sedikit perempuan justru berpendapat bahwa menonjolkan keindahan tubuh mereka adalah sah-sah saja, terutama para perempuan yang terlibat dalam iklan.

Begitu banyaknya iklan yang dahulu dianggap tabu oleh masyarakat, kini menjadi bagian dari keseharian. Media telah mendukung peran eksploitasi perempuan dalam iklan. Begitu banyak iklan yang mengandung eksploitasi perempuan hingga sulit dibedakan apa itu bentuk eksploitasi atau bukan. Sebagai contoh adalah sebuah iklan produk susu pelangsing tubuh untuk perempuan. Banyak iklan seperti ini yang terkadang justru tidak menonjolkan produknya. Keunggulan produk kemudian direpresentasikan oleh perempuan sebagai simbol kesuksesan produk tersebut. Perempuan sebagai objek yang dijual. Menjual tubuh seksi, menarik, dengan mengatas namakan tubuh ideal. Perempuan dalam iklan seperti ini adalah komoditas pasar yang keindahan tubuhnya dijual. Iklan seperti ini tidak menjual produk susu pelangsing, tetapi menjual tubuh perempuan. Karena tidak ada satu gelas atau satu kotak susu pun yang merepresentasikan produk mereka.

Perempuan dan iklan memang sulit dipisahkan. Perempuan bisa memiliki kekuatan dalam membantu menjual produk yang diiklankan. Karena itulah, keberadaan perempuan dalam iklan selalu dibangun untuk merepresentasikan produ-produk dengan segudang pencitraannya, baik itu iklan telepon seluler, rokok, sepatu, obat-obatan, makanan, bank, perumahan, lembaga pendidikan, dan busana. Karakteristik yang mencirikan keperempuanan sebagai kodrat, skarang justru dimanfaatkan sebagai aset dalam dunia periklanan.

\section{SEMIOTIKA ROLAND BARTHES}

Roland Barthes melontarkan konsep tentang konotasi dan denotasi sebagai kunci dari analisisnya. Barthes menggunakan versi yang jauh lebih sederhana saar membahas model 'glossematic sign' (tanda-tanda glossematic). Mengabaikan dimensi dari bentuk dan substansi, Barthes mendefinisikan sebuah tanda (sign) sebagai sebuah sistem yang terdiri dari (E) sebuah ekspresi atau signifier dalam hubungannya (R) dengan content (atau signified) (C): ERC. Sebuah sistem tanda primer (primary sign system) dapat menjadi sebuah elemen dari sebuah sistem tanda yang lebih lengkap dan memiliki makna yang berbeda ketimbang semula. Bartes menulis, Such sign system can become an element of a more comprehensive sign system. If the extension in one of content, the primary sign (E1R1C1) become the expression of a secondary sign system: $\mathrm{E} 2=(\mathrm{E} 1 \mathrm{R} 1 \mathrm{C} 1) \mathrm{R} 2 \mathrm{C} 2 " 30$. Dengan begitu, primary sign adalah denotative 
sedangkan secondary sign adalah satu dari connotative semiotics. Konsep connotative inilah yang menjadi kunci penting dari model semiotika Roland Barthes (Wibowo:2013,21)

Lewat model ini Barthes menjelaskan bahwa signifikan tahap pertama merupakan hubungan antara signifier (ekspresi) dan Signifiedn (content) di dalam sebuah tanda terhadap realitas external. Itu yang disebut Barthes sebagai denotasi yaitu makna yang paling nyata dari tanda (sign). Konotasi adalah istilah yang digunakan Barthes untuk menunjukkan signifikasi tahap kedua (Wibowo:2013,21). Konotasi mempunyai makna yang subjektif atau paling tidak intersubjektif. Dengan kata lain, denotasi adalah apa yang digambarkan tanda terhadap sebuah objek, sedangkan makna konotasi adalah bagaimana cara menggambarkanya (Wibowo:2013,22).

Pada signifikasi tahap kedua yang berhubungan dengan isi, tanda bekerja memalui mitos (myth). Motis adalah bagaimana kebudayaan menjelaskan atau memahami beberapa aspek tentang realitas atau gejala alam. Mitos merupakan produk kelas sosial yang sudah mempunyai suatu dominasi. Mitos primitive, misalnya mengenai hidup dan mati, manusia dan dewa. Sedangkan mitos masa kini misalnya mengenai feminimitas, maskulinitas, ilmu pengetahuan dan kesuksesan. Mitos adalah suatu wahana dimana suatu ideologi berwujud. Mitos dapat berangkai menjadi Mitologi yang memainkan peranan penting dalam kesatuankesatuan budaya (Wibowo:2013,22).

\section{PEMBAHASAN}

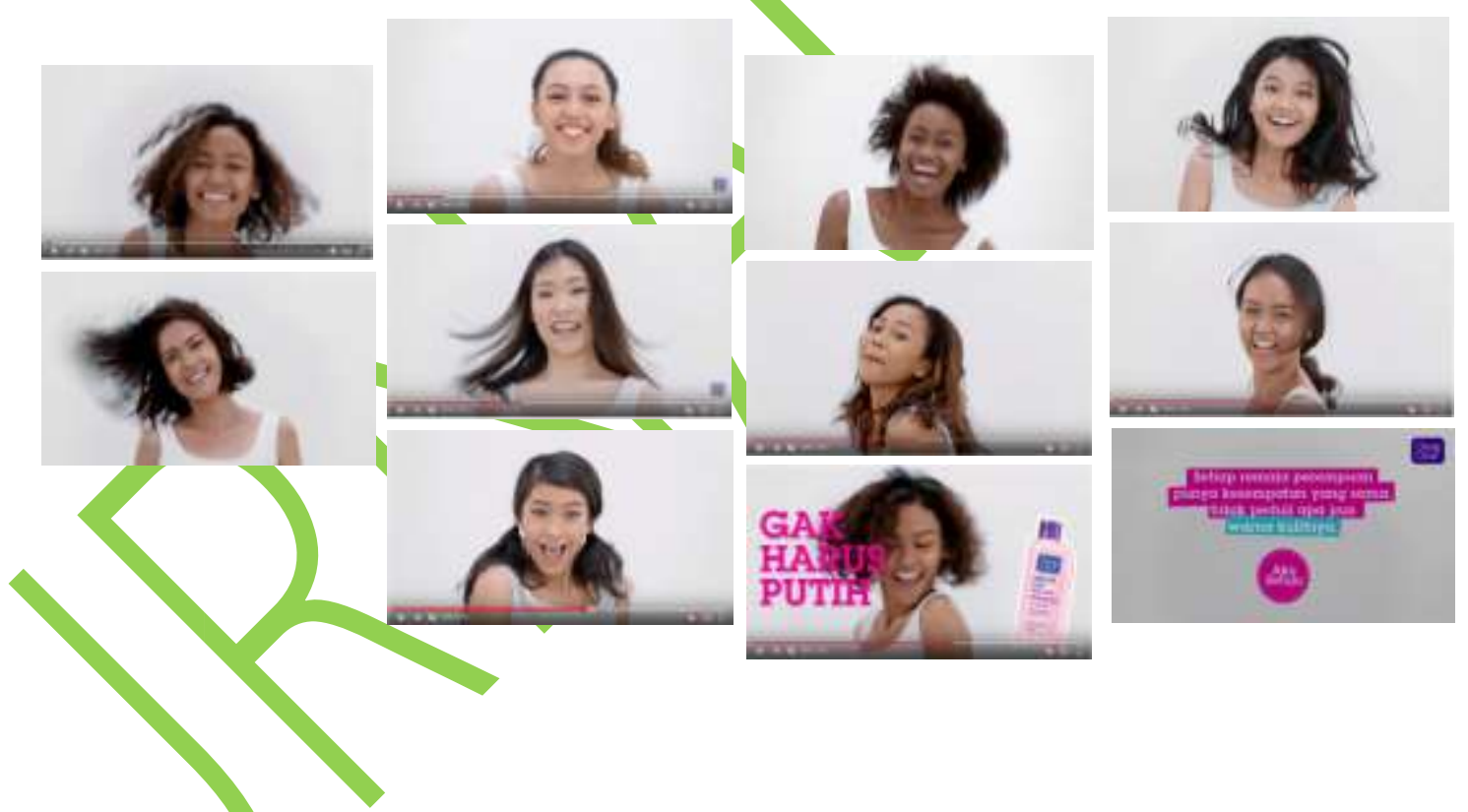

Gambar 1.1. Iklan Clean \& Clear versi '1000 suku Indonesia, warna kulit berbeda'

Iklan berdurasi 50 detik ini memperlihatkan penampilan sembilan perempuan dengan kulit dan jenis rambut yang berbeda, iklan ini juga memberikan pernyataan mengenai mengapa perempuan Indonesia harus menjadi putih. Iklan Clean \& Clear versi 1.000 Suku Indonesia, Warna Kulit Berbeda" memiliki konsep yang berbeda. 
JURNAL LISKI | Vol. 4. No. 1 | 2018

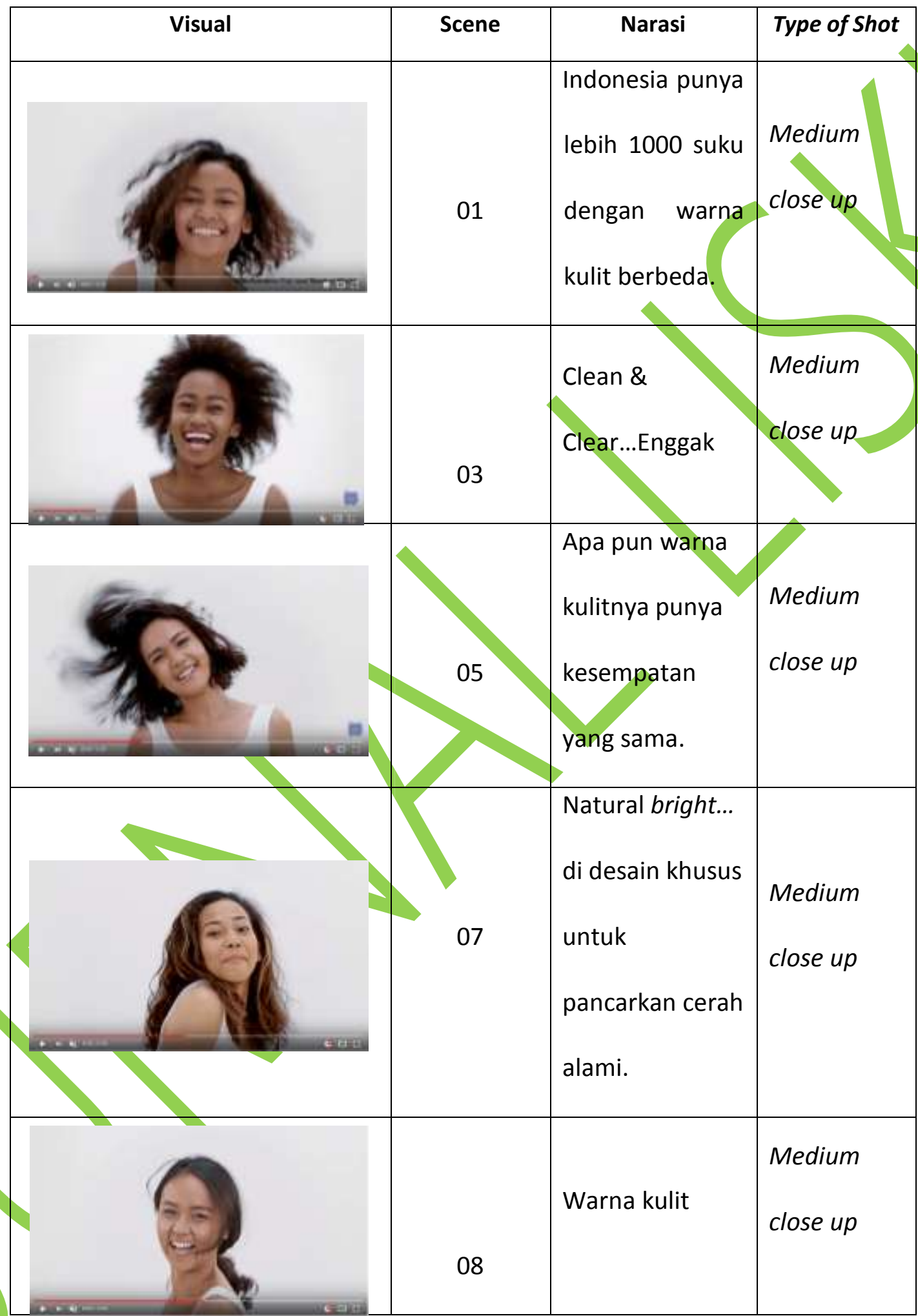




\begin{tabular}{|c|c|l|l|}
\hline Visual & Scene & \multicolumn{1}{|c|}{ Narasi } & Type of Shot \\
\hline & 09 & $\begin{array}{l}\text { Yang alam telah } \\
\text { berikan untukmu }\end{array}$ & $\begin{array}{l}\text { Medium } \\
\text { close up }\end{array}$ \\
\hline
\end{tabular}

Gambar 1.2. 7 perempuan dalam Iklan berjenis kulit gelap, berambut tidak hitam, bertubuh langsing.

Secara keseluruhan, makna denotasi terlihat pada 6 orang model perempuan dengan warna kulit gelap dan memiliki rambut pendek atau keriting, terlihat menari mengikuti irama musik, membolak-balikan wajahnya dari arah kiri dan kanan. Semua adegan ini dilakukan di sebuah ruangan dengan nuansa putih. Rambut keriting ikal khas Indonesia Timur terlihat pada scene ke-1, ke-3 dank ke-10. Perempuan berambut pendek berwarna hitam terlihat di scene ke-5. Sementara di scene ke-7, perempuan terlihat berambut panjang bergelombang dengan warna cat rambut kecoklat-coklatan. Scene 9 menampilkan perempuan dengan rambut panjang terikat tidak rapi. Semua perempuan ini terlihat ber make-up natural. Semua perempuan ini menggunakan baju yang sama berjenis tanktop atau kaos tanpa lengan berwarna putih. Seluruh scene menggunakan ukuran shoot Medium Close Up (MCU), kecuali scene ke 10. Dari sisi wardrobe, property, ukuran frame dan penataan cahaya, semuanya sama. Musikpun mengalir, menyatukan shot-shot tersebut menjadi satu kesatuan. Dari sisi narasi, kita dapat dengan jelas mendengarkan seorang narator perempuan menyampaikan informasi tentang kecantikan.

Indonesia punya lebih 1000 suku dengan warna kulit berbeda. Kenapa semua orang harus putih. Clean \& Clear...Enggak. Kenapa semua orang harus putih?. Apa pun warna kulitnya punya kesempatan yang sama. Makanya kami membuat Natural bright, di desain khusus untuk pancarkan cerah alami. Warna Kulit yang alam telah berikan untukmu. Lagian, kamu gak harus jadi putih kok. Bantu kami ubah cara pandang warna kulit dan dukung gerakan ini.

Makna Konotasi terlihat dari senyuman mereka menunjukkan ekspresi senang yang timbul dari suasana hati serta menggambarkan sebuah kebahagiaan pada diri mereka. Tarian mereka memperlihatkan bagaimana mereka merasa nyaman, lepas dan menikmati alunan musik yang mengiringinya. Pemilihan jenis baju tanktop yang dikenakannya juga memperlihatkan bagaimana keinginan mereka untuk tetap tampil percaya diri walaupun berkulit gelap. Ke-7 scene dalam iklan Clean \& Clear versi 1000 suku Indonesia Warna kulit berbeda, memberikan sebuah gambaran yang berbeda secara visual, tentang perbedaan jenis kulit yang ada di Indonesia. 3 konsep cantik yang telah melekat di dalam benak masyarakat Indonesia, yaitu kulit putih, rambut panjang dan hitam serta tubuh yang langsing oleh Clean \& Clear coba dikonstruksi ulang. Clean \& Clear tidak hanya menampilkan perempuan berkulit putih dan ber-rambut hitam panjang, namun mereka juga menampilkan perempuan dengan warna kulit gelap dan berambut pendek serta ikal. Jika diperhatikan, maka prosentase dari 
model perempuan berkulit putih dan berambut hitam panjang lebih sedikit. Clean \& Clear secara explisit terlihat dengan sengaja menonjolkan perbedaan itu secara visual.

Jika dilihat dari struktur kalimatnya, maka narasi ini terdiri atas informasi secara umum tentang keberagaman Indonesia, Indonesia punya lebih 1000 suku dengan warna kulit berbeda, kemudian sebuah pertanyaan tentang mitos yang ada selama ini, yaitu cantik itu berkulit putih. Pertanyaan ini dimunculkan berdasarkan social exsperiment yang dilakukan oleh Clean \& Clear (sebelum memproduksi iklan ini) yaitu tentang cara pandang orang Indonesia terhadap kecantikan perempuan, yang hasilnya ternyata kebanyakan orang memilih perempuan berkulit putih sebagai representasi sebuah kecantikan. Berdasarkan data tersebut, kemudian Clear \& Clean mencoba tampil beda dan secara explisit menyampaiakn dalam iklan bahwa Clear \& Clean...Enggak. Narasi selanjutnya adalah "Kenapa semua orang harus putih?". Melalui kalimat pertanyaan ini Clear \& Clean mencoba untuk berempati terhadap perempuan yang tidak berkulit putih. Ini adalah sebuah cara yang menarik, karena kita tahu, lebih banyak perempuan Indonesia berkulit gelap dibandingkan berkulit putih. Seperti yang telah disampaikan di latar belakang sebelumnya, bahwa cantik itu bersifat kultural, sangat bergantung pada kultur yang ditempati dan pada dasarnya, orang Indonesia berkulit gelap. Narasi berikutnya, Apa pun warna kulitnya punya kesempatan yang sama, Clear \& Clean menyampaikan bahwa cantik itu milik semua orang, dan semua perempuan ber hak mendapatkan predikat cantik. Hal ini coba direpresentasikan oleh iklan ini melalui tampilan perempuan yang sangat percaya diri dengan kulit gelap mereka, gerakan enerjik dan senyum lepas seolah memberikan contoh kepada para perempuan berkulit gelap untuk tetap ceria, optimis dan selalu berpikir positif dan terus menumbuhkan rasa percaya diri. Celan \& Clear kemudian menawarkan sebuah solusi yang apik, tidak perlu berkulit putih, namun cukup dengan berkulit bersih, sehingga warna alami akan terpancar dari kulit yg berwarna gelap sekalipun. Sebuah alternatif jalan tengah yang coba ditawarkan kepada perempuan berkulit gelap. Hal ini diperkuat dengan narasi Lagian, kamu gak harus jadi putih kok. Menjadi menarik ketika narasi terakhir dalam iklan ini berbunyi Bantu kami ubah cara pandang warna kulit dan dukung gerakan ini. Pemilihan kata gerakan, menurut penulis menjadi menarik, karena gerakan dapat diartikan sebagai sebuah tindakan terencana yang ditujukan pada suatu perubahan. Pemilihan kata gerakan ini seolah ingin memposisikan bahwa iklan ini seperti sebuah gerakan sosial mengenai cara pandang perempuan tentang kecantikan. Seperti yang telah disampaikan pada latar belakang tulisan ini bahwa pada dasarnya cantik tidak dapat digambarkan oleh ciri fisik, karena kontruksi cantik di berbagai negara memiliki arti yang berbeda-beda

Secara ekplisit, narasi ini mencoba menegaskan pesan visualisasi dari ke-7 perempuan tersebut. Jika diperhatikan, antara visual dan narasi terkesan terjadi pengulangan penyampaian pesan. Namun demikian, menurut hemat penulis, seandainya visualisasi perempuan-perempuan tersebut tidak didukung dengan narasi, maka persepsi penonton mungkin bisa berkembang liar, sehingga memungkinkan pesan yang ingin disampaikan terdistorsi. Sehingga narasi-narasi tersebut perlu disampaikan agar pesan lebih jelas diterima oleh penonton. 


\begin{tabular}{|c|l|l|l|}
\hline Visual & Scene & Narasi & Type of Shot \\
\hline & 02 & $\begin{array}{l}\text { Kenapa semua } \\
\text { orang ingin } \\
\text { keliatan putih }\end{array}$ & $\begin{array}{l}\text { Medium } \\
\text { close up }\end{array}$ \\
\hline & 04 & $\begin{array}{l}\text { Karena kita } \\
\text { percaya semua } \\
\text { remaja } \\
\text { perempuan }\end{array}$ & $\begin{array}{l}\text { Medium } \\
\text { close up }\end{array}$ \\
\hline
\end{tabular}

Gambar 1.3.

3 perempuan dalam $\mathbf{k l a n}$ berjenis kulit putih, berambut hitam, bertubuh langsing.

Sementara terdapat tiga orang model perempuan yang memiliki kulit putih, berambut hitam panjang dan bertubuh langsing, juga terlihat menari bebas mengikuti irama musik, dengan kaos tanpa lengan berwarna putih sehingga warna kulit mereka juga terlihat jelas. Bila kita perhatikan, pemaknaan denotasi tidak ada perbedaan dengan tujuh scene sebelumnya yang notabene menampilkan perempuan berkulit gelap. Dalam scene ini, mereka juga tampil dengan enerjik, sama dengan perempuan yang berkulit gelap.

Secara pemaknaan konotatif, tiga scene yang menampilkan perempuan berkulit putih sama dengan tujuh scene yang menampilkan perempuan berkulit gelap. Senyum lepas menggambarkan seorang perempuan yang memiliki jiwa positif, dan adegan ini tidak ada bedanya dengan perempuan berkulit gelap. Pakaian yang digunakan juga identik, tanktop warna putih, sehingga kulit mereka jelas terlihat. Tiga scene ini adalah representatif dari konstruksi cantik yang ada di Indonesia. Kulit putih, rambut panjang dan tubuh langsing. Jika kita perhatikan, penampilan antara perempuan berkulit gelap dan putih di tampilkan dengan cara bergantian. Scene dengan perempuan berkulit gelap ada pada scene 1, 3, 5, 7,8,9,10. Sedangkan scene dengan kulit putih ada pada scene 2,4,6. Secara kuantitaif, Clear \& Clean jelas 'mendukung' kulit gelap. Pengaturan tampilan secara bergantian antara kulit gelap dan kulit putih akan menunjukkan kekontrasan di awal iklan. Kemudian setelah scene 6, maka perempuan yang ditampilkan semuanya berkulit gelap. Hal ini adalah bagian penekanan bahwa kulit gelap lebih mendominasi. Pesan Clear \& Clean untuk mengubah cara pandang penonton tentang kecantikan menurut penulis juga sangat memperhatikan urutan penampilan talent. Perempuan berkulit gelap ditampilkan di awal scene. Jika kita perhatikan, perempuan yang ditampilkannya pun adalah perempuan yang identik dengan sosok perempuan dari Indonesia Timur dan di tutup pula dengan penampilan perempuan yang sama dengan scene pertama. Artinya, Clear \& Clean mencoba untuk menonjolkan cirikas orang Indonesia.

Iklan Clean \& Clear versi 1000 suku Indonesia, Warna kulit berbeda memberikan sebuah gambaran yang berbeda tentang bagaimana jenis kulit yang ada di Indonesia. Indonesia terdiri dari 1000 suku yang mengartikan Indonesia memiliki jenis-jenis kulit yang 
berbeda-beda. Dengan memperlihatkan model-model perempuan yang tampil dengan kepercaya diri yang tinggi, Clean \& Clear ingin menyampaikan pesan bahwa kecantikan inner beuty harus tumbuh pada perempuan Indonesia, sehingga akan membuat orang-orang yang melihat akan terkesan dengan sikap percaya dirinya,

\section{MITOS DALAM IKLAN}

Mitos yang berkembang dalam masyarakat kita tentang warna kulit perempuan, bahwa warna kulit ini dijadikan sebagai pembeda tingkat sosial seseorang di masyarakat. Dalam sejarah Jawa Kuno di gambarkan dalam kisah Ramayana, perempuan dengan warna kulit terang dan berambut panjang direpresentasikan sebagai perempuan yang cantik dan di inginkan oleh laki-laki. Kemudian perempuan berkulit gelap dan berambut tidak panjang direpresentasikan sebagai perempuan yang tidak diinginkan. Mitos lainnya terkait kecantikan muncul pada masa penjajahan Jepang (1942-1945) yang beranggapan bahwa simbol kecantikan dari Asia adalah perempuan dengan kulit putih. Bagi perempuan pada masa itu menjadi seorang yang berkulit putih sangat membanggakan dan bagi perempuan dengan warna gelap tidaklah bisa di anggap sebagai wanita yang cantik.

Perempuan yang ada pada iklan Clean \& Clear versi '1000 Suku Indonesia, Warna Kulit Berbeda' beberapa diantaranya digambarkan sangat berbeda dengan perempuan yang ada di mitos tersebut. Iklan Clean \& Clear versi '1000 Suku Indonesia, Warna Kulit Berbeda' memperlihatkan bagaimana perempuan yang menarik tidak hanya dilihat dari jenis kulitnya dan rambutnya saja, tetapi juga harus dilihat dari sisi inner beauty. Setiap perempuan memiliki sisi kecantikan dari dalam, sehingga mereka punya hak untuk tetap cantik, apapun bentuk fisiknya. Iklan ini mencoba memberikan gambaran tentang perempuan yang harus mempunyai kepercayaan diri yang tinggi, kepribadian yang baik serta berkharisma, sehingga dapat menciptakan aura positif bagi siapapun yang melihatnya.

Mitos kecantikan lain yang ada di dalam masyarakat adalah perempuan yang bertubuh langsing di nilai sebagai perempuan cantik. Langsing merupakan bentuk tubuh yang ideal bagi seorang perempuan, sehingga membuatnya terlihat cantik. Dari sembilan model remaja perempuan yang ada di dalam iklan Clean \& Clear versi '1000 Suku Indonesia, Warna Kulit Berbeda', semuanya memperlihatkan jenis tubuh perempuan yang langsing, sehingga iklan ini seakan 'membenarkan' mitos yang menyatakan perempuan cantik itu harus bertubuh langsing.

\section{SIMPULAN}

Pemaknaan denotasi dalam iklan ini memperlihatkan tiga perempuan berkulit putih, enam perempuan berkulit gelap. Seluruh perempuan yang ditampilkan bertubuh langsing. Mereka melakukan adegan sama, yaitu menari secara bebas dengan mengikuti irama musik. Latarbelakang dan pakaian yang digunakan juga sejenis. Secara konotasi, model perempuan yang ada dalam iklan ini menjelaskan bahwa perempuan yang cantik adalah perempuan yang memiliki kepercayaan diri, memiliki kepribadian yang baik serta dapat menciptakan aura yang positif bagi lingkungan sekitarnya. Hal tersebut ditujukkan melalui adegan tarian yang energik dengan senyum lepas dan gerakan yang cenderung bebas, tidak beraturan, tetapi tetap mengikuti irama musik. Perempuan berkulit putih, gelap, berambut panjang, pendek, lurus, ikal, keriting, berwarna merah, hitam, semua memiliki kesempatan yang sama, kesamaan pakaian yang dikenakan, musik yang mengiringi, latar belakang serta durasi mereka tampil.

Dalam kaitannya dengan mitos, maka pemaknaan yang dapat dilihat bahwa Iklan Clean \& Clear ini mencoba untuk memberikan counter terhadap mitos yang ada sebelumnya, bahwa cantik tidak harus berkulit putih dan berambut hitam panjang. Semua remaja perempuan punya hak yang sama untuk merasa cantik, tanpa membedakan jenis kulit dan rambut. Berdasarkan 3 konsep pengkategorian kecantikan yang telah disampaikan sebelumnya, ada 1 
kategori yang tidak dilakukan oleh iklan Clean \& Clear, yaitu kategori tubuh yang langsing. Iklan Clean \& Clear ini masih menampilkan 9 model remaja perempuan bertubuh langsing. Namun, untuk kecantikan pada kategori tubuh langsing, Clean \& Clear tidak melakukan counter terhadap kategori ini. Terbukti dengan ke-sembilan model remaja perempuan yang ditampilkan, semuanya bertubuh langsing. Bagi penulis, hal ini cukup menimbulkan pertanyaan, mengapa Clean \& Clear tidak 'berani' meng-counter mitos yang satu ini. Bila kulit gelap dan rambut keriting bisa mereka citrakan menjadi orang yang percaya diri dan dapat menciptakan aura yang positif bagi penontonnya, mengapa pada kategori tubuh langsing tidak dilakukan?

SARAN

Penulis berharap penelitian ini dapat dijadikan sebagai stimulant bagi para penulis lainnya untuk dapat melakukan analisa terhadap iklan-iklan lainnya serta memperkaya kajiankajian analisa semiotika dalam ranah ilmu komunikasi.

Saran praktis dari penulis, penulis tidak melihat adanya hal yang harus diperbaiki. Penataan lampu, pemilihan sudut pandang kamera, dan pemilihan Medium Close Up dalam sebagian besar ukuran shoot menurut penulis sudah tepat. Namun ada satu hal yang terlihat kurang halus dalam transisi gambar. Perpindahan obyek dari perempuan satu ke perempuan yang lain terlihat kurang halus dan kurang rapi. Salah satu hal yang bisa dilakukan agar transisi tidak terlihat janggal dengan menggunakan efek morphing. Efek ini dapat menghasilkan efek perpindahan dari obyek satu ke obyek lainnya dengan sangat halus. Alternatif lain adalah menggunakan efek jump cut, sehingga pergantian gambar akan terlihat dengan jelas, ini akan terkesan lebih alami, sesuai konsep iklan yang ingin menampilkan segala sesuatu apa adanya.

\section{DAFTAR PUSTAKA}

Andi Prastowo. (2011). Metode Penelitian Kualitatif dalam Perspektif Rancangan Penelitian. Jogjakarta. Ar-Ruzz Media

Barthes, Roland. 2012. Elemen-Elemen Semiotika. Terjemahan M. Ardiansyah. Jogjakarta: IRCiSoD

Bungin, Burhan. (2010). Konstruksi Sosial Media Massa. Jakarta. Kencana

Deddy, Mulyana. (2010). Metodologi Penelitian Kualitatif. Bandung. PT. Remaja Rosdakarya

Sobur, Alex. (2013). Semiotika Komunikasi. Bandung. Remaja Rosdakarya.

Sugiyono. (2014). Memahami Penelitian Kualitatif. Bandung. Alfabeta

Wijayanti, Daru. (2009). Rahasia Cantik Luar Dalam. Jogjakarta. Flamingo.

Wibowo, Indiwan Seto Wahyu. (2013). Semiotika Komunikasi Aplikasi Praktis Bagi Penelitian dan Skripsi Komunikasi. Jakarta. Mitra Wacana Media 